\title{
Hemifacial spasm and psychiatric comorbidities
}

\author{
Hemifasial spazm ve psikiyatrik komorbiditeler
}

Taner Değirmenci

Gönderilme tarihi:15.02.2022

Kabul tarihi:07.03.2022

\begin{abstract}
Purpose: In Hemifacial spasm (HFS) uncontrolled movements may affect interpersonal communication and these patients may suffer from stigma, depression and anxienty. In this study we aimed to evaluate depression and axiety in patients with HFS and it's relation with self-stigmatization.

Materials and methods: This is a cross-sectional observational study conducted in 27 patients with HFS and 36 healthy controls. Turkish version of The Internalized Stigma of Mental Illness (ISMI) scale, and Hamilton depression and anxiety scales were performed in both groups. Independent samples t test was used to compare the numeric data between groups and Pearson correlation test is used to investigate the correlation of scales' scores.

Results: There was statistically significant difference in mean values of ISMI, HDRS-17 and HAMA scores. There was not statistically significant correlation between ISMI and HDRS-17 and HAMA scores, but we found strong correlation between HDRS-17 and HAMA scores ( $r: 0.928, p: 0.000)$.

Conclusion: Our results suggest that depression and anxiety are common in patients with HFS and stigmatization is an important social problem for these patients. To be aware of this, would be helpful for both psychiatric and neurological condition of the patients with HFS.
\end{abstract}

Key words: Hemifacial spasm, depression, anxiety, stigmatization.

Degirmenci T. Hemifacial spasm and psychiatric comorbidities. Pam Med J 2022;15:375-378.

Öz

Amaç: Hemifasiyal spazmda (HFS) kontrolsüz hareketler kişilerarası iletişimi etkileyebilir ve bu hastalarda damgalanma, depresyon ve kaygı olabilir. Bu çalışmada, HFS'li hastalarda depresyon ve anksiyetenin kendini damgalama ile ilişkisini değerlendirmeyi amaçladık.

Gereç ve yöntem: Bu çalışma HFS'li 27 hasta ve 36 sağlıklı kontrol üzerinde yürütülen kesitsel gözlemsel bir çalışmadır. Ruhsal Hastalıkların İçselleştirilmiş Damgalanması (ISMI) ölçeğinin Türkçe versiyonu ile Hamilton depresyon ve anksiyete ölçekleri her iki gruba da uygulandı. Gruplar arasındaki sayısal verilerin karşılaştırılmasında bağımsız örneklemler t testi ve ölçek puanlarının korelasyonunu araştırmak için Pearson korelasyon testi kullanımıştır.

Bulgular: ISMI, HDRS-17 ve HAMA skorlarının ortalama değerlerinde istatistiksel olarak anlamlı fark vardı. ISMI ile HDRS-17 ve HAMA puanları arasında istatistiksel olarak anlamlı bir ilişki yoktu, ancak HDRS-17 ve HAMA puanları arasında güçlü bir ilişki bulduk ( $r: 0.928, p: 0.000)$.

Sonuç: Sonuçlarımız, HFS'li hastalarda depresyon ve anksiyetenin yaygın olduğunu ve bu hastalar için damgalanmanın önemli bir sosyal sorun olduğunu göstermektedir. Bunun farkında olmak, HFS'li hastaların hem psikiyatrik hem de nörolojik durumları için faydalı olacaktır.

Anahtar kelimeler: Hemifasiyal spazm, depresyon, anksiyete, damgalama.

Değirmenci T. Hemifasial spazm ve psikiyatrik komorbiditeler. Pam Tıp Derg 2022;15:375-378.

Taner Değirmenci, M.D. Denizli Ozel Saglik Hospital, Psychiatry Clinic, Denizli, Turkey, e-mail: tanerd75@gmail.com (https://orcid.org/00000002-6810-9710) (Corresponding Author) 


\section{Introduction}

Hemifacial spasm (HFS) manifests as involuntary, tonic, or clonic contractions of muscles involving one side of the face and HFS may cause significant social distress consequent to unpredictable facial twitching, leading to depression, poor social interactions, and difficulties with vision, which results in an overall decreased quality of life [1]. In HFS uncontrolled movements may affect interpersonal communication and these patients may suffer from stigma and depression [2]. Self-stigmatization is a step-by-step process during which the person uncritically accepts the societal negative evaluation and applies it to himself [3]. Self-stigma frequently leads to dysphoria and decline in self-esteem and quality of life (QoL) [4]. In this study we aimed to evaluate depression and axiety in patients with HFS and it's relation with self-stigmatization.

\section{Materials and methods}

A total of 27 patients with HFS and 36 healthy control subjects enrolled to this study. No individuals with a history of psychiatric disorder and/or a serious somatic disorder and/or any other neurological disorder were included. Ethics committee of Pamukkale University approved the study, and all patients and control groups signed an informed consent. The investigation was carried out according to the latest version of the Declaration of Helsinki [5].

\section{Scales}

Turkish version of The Internalized Stigma of Mental IIIness (ISMI) scale [6], and Hamilton depression and anxiety scales [7, 8] were performed in both groups. ISMI has 29 items that evaluate the different areas of the internalized stigma. In this study total ISMI score was used to compare the difference of stigmatization between two groups. Depression was evaluated using the 17-item version of Hamilton Rating Scale for Depression (HDRS-17) and anxiety was evaluated using Hamilton Anxiety Rating Scale (HAMA) score.

\section{Statistics}

SPSS version 22.0 was used for the statistical analysis. Independent samples $t$ test was used to compare the numeric data between groups and Pearson correlation test is used to investigate the correlation of scales' scores. If the $p$-value was $<0.05$, the result was considered to be statistically significant.

\section{Results}

The mean age was similar between the HFS and control groups (Mean \pm SD in patient and control groups $60.63 \pm 7.96$ and $42.96 \pm 10.29$, $p$ value:0,22) and both groups had a similar proportion of male and female patients (The ratio of females was $74.1 \%$ in patient group and $69.4 \%$ in control group ( $p$ value:0.78).

There was statistically significant difference in mean values of ISMI, HDRS-17 and HAMA scores (Table 1). Correlations analyses of patient group's scales scores are shown in Table 2. There was not statistically significant correlation between ISMI and HDRS-17 and HAMA scores, but we found strong correlation between HDRS-17 and HAMA scores (r:0.928, p:0.000).

Table 1. Comparison of ISMI, HDRS-17 and HAMA scores among patients and controls

\begin{tabular}{llll}
\hline Scales & Patients & Control & p value \\
& Mean \pm SD & Mean \pm SD & \\
\hline ISMI & $75.37 \pm 11.00$ & $60.39 \pm 13.03$ & 0.000 \\
HDRS-17 & $60.50 \pm 9.03$ & $15.33 \pm 8.45$ & 0.000 \\
HAMA & $32.75 \pm 11.68$ & $13.93 \pm 8.41$ & 0.000 \\
\hline
\end{tabular}

ISMI: The Internalized Stigma of Mental IIIness

HDRS-17: 17-item version of Hamilton Rating Scale for Depression HAMA: Hamilton Anxiety Rating Scale 
Table 2. Correlation of Comparison of ISMI, HDRS-17 and HAMA scores in patient group

\begin{tabular}{lllll}
\hline & & ISMI & HDRS-17 & HAMA \\
\hline ISMI & Pearson Correlation & 1 & .195 & .102 \\
& Sig. (2-tailed) & & .329 & .611 \\
& $\mathrm{~N}$ & 27 & 27 & 27 \\
HDRS-17 & Pearson Correlation & .195 & 1 & $.928^{* *}$ \\
& Sig. (2-tailed) & .329 & & .000 \\
HAMA & $\mathrm{N}$ & 27 & 27 & 27 \\
& Pearson Correlation & .102 & $.928^{* *}$ & 1 \\
& Sig. (2-tailed) & .611 & .000 & \\
& $\mathrm{~N}$ & 27 & 27 & 27 \\
**. Correlation is significant at the 0.01 level (2-tailed) & \\
\hline
\end{tabular}

ISMI: The Internalized Stigma of Mental IIIness

HDRS-17: 17-item version of Hamilton Rating Scale for Depression HAMA: Hamilton Anxiety Rating Scale

\section{Discussion}

Social embarrassment was reported in $41 \%$ of HFS patients [9]. HFS-associated nonmotor symptoms like interference with vision, hypoacusis, facial pain, dysarthria and trismus were reported in the literature [10] but studies evaluating psychiatric profile of the patients like self-stigmatization is rare. In our study we found that ISMI, HDRS-17 and HAMA scores were significantly different between patient and control groups. Anxiety and depression are special conditions and can affect quality of life in patients with movement disorders. In rural areas this kind of involuntary facial movements may be attributed to unsuitable gestures by some peoples. Spasms at the faces may affect interpersonal communication, and emotional problems can aggravate facial symptoms [11]. The ISMI scale was previously used in different patient groups that have chronical diseases like epilepsy, leprosy, inflammatory bowel diseases and substance abuse [12]. In this study we used 29-item ISMI survey, to evaluate the correlation of stigmatization with depression and anxiety in patients with HFS.

It is reported that $15 \%-30 \%$ of HFS patients have anxiety/depression, both higher than the anxiety/depression rate of the general population [13]. In our study both depression and anxiety scores were higher in-patient group, and these results are consistent with the literature.

The ISMI scale measures the internalized stigma experienced from other socially discrediting conditions with modification. Stigmatization has many negative consequences, like isolation, treatment delay, higher level of psychopathology and lesser quality of life [14]. This is important for the patients with HFS that is a chronic condition that requires regular clinical follow-ups and botulinum toxin injections. To be aware of psychiatric comorbidities of the patients with HFS would be helpful for the neurologists in clinical practice.

In our study, there was not statistically significant correlation between ISMI and HDRS17 and HAMA scores. Although there are a small number of studies about psychiatric comorbidities in patients with HFS, to our knowledge of the literature, no definite link between stigma and depression has been determined as our study.

There are some limitations of our study such as small number of groups. In addition, evaluating the treatment effect of botulinum toxin and degree of HFS severity would be more informative.

Finally, our results suggest that depression and anxiety are common in patients with HFS, and stigmatization is an important social problem for these patients. To be aware of this, would be helpful for both psychiatric and neurological condition of the patients with HFS.

Conflict of interest: No conflict of interest was declared by the authors. 


\section{References}

1. Ghali MGZ, Srinivasan VM, Viswanathan A. Microvascular decompression for hemifacial spasm. Int Ophthalmol Clin 2018;58:111-121. http://doi. org/10.1097/IIO.0000000000000209

2. Rinnerthaler M, Mueller J, Weichbold V, Wenning GK, Poewe W. Social stigmatization in patients with cranial and cervical dystonia. Mov Disord 2006;21:1636-1640. http://doi.org/10.1002/mds.21049

3. Latalova K, Prasko J, Kamaradova D, et al. Self-stigma and suicidality in patients with neurotic spectrum disorder - a cross sectional study. Neuro Endocrinol Lett 2014;35:474-480.

4. Holubova M, Prasko J, Ociskova M, Marackova M, Grambal A, Slepecky M. Self-stigma and quality of life in patients with depressive disorder: a cross-sectional study. Neuropsychiatr Dis Treat 2016;12:2677-2687. http://doi.org/10.2147/NDT.S118593

5. Ritsher JB, Otilingam PG, Grajales M. Internalized stigma of mental illness: psychometric properties of a new measure. Psychiatry Res 2003;121:31-49. http:// doi.org/10.1016/j.psychres.2003.08.008

6. Ersoy MA, Varan A. Ruhsal hastaliklarda içselleştirilmiş damgalanma ölçeği türkçe formu'nun güvenilirlik ve geçerlik çalişmasi. Turk Psikiyatri Derg 2007;18:163171.

7. Akdemir A, Örsel DS, Dag İ, Türkçapar MH, İscan N, Özbay H. Hamilton depresyon derecelendirme ölçeği (HDDÖ)'nin geçerliliği- güvenirliliği ve klinikte kullanımı. Psikiyatri Psikoloji Psikofarmakoloji Derg 1996;4:251259.

8. Yazıcı MK, Demir B, Tanrıverdi N, Karaağaoğlu E, Yolaç P. Hamilton anksiyete değerlendirme ölçeği, değerlendiriciler arası güvenirlik ve geçerlik çalışması. Türk Psikiyatri Derg 1998;2:114-117.

9. Wang A, Jankovic J. Hemifacial spasm: clinical findings and treatment. Muscle Nerve 1998;21:1740-1747.http://doi.org/10.1002/(sici)10974598(199812)21:12<1740::aid-mus17>3.0.co;2-v

10. Rudzińska M, Wójcik M, Szczudlik A. Hemifacial spasm non-motor and motor-related symptoms and their response to botulinum toxin therapy. J Neural Transm (Vienna) 2010;117:765-772. http://doi.org/10.1007/ s00702-010-0416-5

11. Lawes Wickwar S, McBain $\mathrm{H}$, Hirani SP, et al. Which factors impact on quality of life for adults with blepharospasm and hemifacial spasm? Orbit 2021;40:110-119. http://doi.org/10.1080/01676830.20 20.1733028

12. Boyd JE, Adler EP, Otilingam PG, Peters T. Internalized Stigma of Mental IIIness (ISMI) scale: a multinational review. Compr Psychiatry 2014;55:221-231. http://doi. org/10.1016/j.comppsych.2013.06.005
13. Kaushik A, Kostaki E, Kyriakopoulos M. The stigma of mental illness in children and adolescents: a systematic review. Psychiatry Res 2016;243:469-494. http://doi. org/10.1016/j.psychres.2016.04.042

14. Ritsher JB, Phelan JC. Internalized stigma predicts erosion of morale among psychiatric outpatients. Psychiatry Res 2004;129:257-265. http://doi. org/10.1016/j.psychres.2004.08.003

Ethics committee approval: Pamukkale University Non-Interventional Clinical Research was evaluated by the ethics committee and the committee convened on 09.01.2015 and decided that there is no ethical objection with the number 60116787-020/1015. 